\title{
Black and British? History, Identity and Citizenship
}

\section{Andrew Wrenn}

\begin{abstract}
This paper will explore some of the tensions and contradictions in being labelled 'black' and 'British' within the United Kingdom, set against the discourses about the historic development of British and other identities as well as strands of post-modern thinking. It will relate these tensions and contradictions to emerging practice in citizenship and history curricula in England at Key Stage 3 level.
\end{abstract}

'The English' by Jeremy Paxman (1998) has been a recent best seller in British bookshops. Paxman quotes the late, black, labour MP Bernie Grant as saying that he would rather be introduced as 'Black British' than English. This hybrid label 'Black British' is appropriate 'because it includes other oppressed people like the Welsh or the Scots. It would stick in my throat to call myself English.' His statement deserves closer examination. Grant appears to imply that the 'English', 'Welsh' and 'Scots' are 'peoples' while the 'British' are not, at least not in the same way. A particular view of the past is also taken as read. The 'English' are cast as historic oppressors while the term 'British' becomes a more neutral label to which the term 'black' can be safely linked. Grant sees himself as belonging to a dual identity, 'black', by implication founded on skin colour and 'British' founded on a looser identity, closer perhaps to legal citizenship of the British state. This citizenship is shared by the English, Scots, Welsh and black people but not on an equal basis, for Grant defines black, British identity against one of these peoples, the English. The shared legacy of past oppression unites Scots, Welsh and blacks as historic victims of another people, the English. In shifting the term 'British' away from a more traditional notion of nationhood, Grant was actually taking part in a much wider discourse about how the concepts of 'nation' and 'Britishness' are 'imagined' in the future. (McKiernan, 1993).

The role of history is crucial in helping to shape how these concepts are 'reimagined'. There is an influential stand of historiography that seeks to redefine what constitutes 'British history' and by implication what we understand as British identity. Colley (1994) asserted that 'Britishness' emerged as a concept in the eighteenth century after the Act of Union (1707) between England \& Scotland. It was founded on a common loyalty to protestant values (among other things) and allowed Scots, and to an extent the other peoples of the then United Kingdom a stake in both imperial and economic expansion. Other historians (Davies, 2000) have asserted that 'British history' has come to mean 'English history'. The other peoples, the Scots, the Welsh and Irish need to reassert their distinct histories so that 'British history' is rewritten to be more representative of all constituent parts of the United Kingdom, not just England. Davies goes out of his way to deconstruct what he views as an anglicising domination of the historic record. He insists that the term 'British' cannot be anachronistically applied to events prior to 1707 since the only substantial use of the label 'British' before this was derived from the Roman province of Britannia. A label that only ever referred to the southern half of the island of Great Britain. When speaking to a conference in Dublin, capital of the long independent Irish Republic it occurred to Davies that referring to the term 'British Isles' in this setting was inappropriate. Thus his book is referred to as just 'The Isles'.

While Davies is claiming to be rewriting 'British' history from a more 'accurate' perspective, the wholesale process of revisionism can be justified even further by reference to strands of post-modern thinking. In 1978 White wrote that historians should be forced "to abandon the attempt to portray one particular portion of life right side up and in the true perspective.....and to recognise that there is no such thing as a correct view'. The very concepts of truth and objectivity can be viewed as elements 
of a modernist paradigm of history deriving from the imperialist west. Paula Rothenberg, (1992) claimed: 'the traditionalist curriculum teaches us to see the world through the eyes of the privileged, white European males and to adopt their interests and perspectives as our own ...effectively defines this point of view as reality rather than a point of view itself, and then assures us that it alone is 'neutral' and 'objective'.'

Zinn (1994) supports this view: 'all history is subjective, all history represents a point of view... and since its not possible to be objective, you should be honest about that.' It is a small step to then espouse that within whatever rules historians can articulate, all interpretations are equally valid. Were such a view to prevail with regard to the historical interpretations of Davies (the professional historian) and Grant (the professional politician), the past would merely become a quarry for the endless restructuring of politics and identity in the present. It would be possible to argue against their points of view but only up to a point since 'all interpretations are equally valid'. If Grant and other blacks choose to define themselves as 'Black and British' and not 'Black and English' by reference to a particular view of the past, that is their choice.

Of course this kind of relativism frequently draws heavy fire from the Right. Kerridge (1998) attacks the very idea of black history from a more modernist perspective: 'Do we need to rewrite the curriculum.... in order to make blacks visible in the books, as they are visible in the streets of modern Britain.... If so what should be changed? Which bits of history must be censored out, which newly included and which rewritten, so as to change the emphasis or even change the facts? They (ed: those questions) lie at the heart of a new intellectual endeavour to produce a black centred curriculum and to overthrow the cultural hegemony of 'racist Britain'.'

Writing in The Guardian of October $9^{\text {th }} 1997$, Norman Tebbit raised the spectre of disintegration and anarchy flowing from pluralistic alternative histories breaking down commonly accepted concepts of British history. 'Youngsters of all races born here should be taught that British history is their history or they will forever be foreigners holding British passports and this kingdom will become a Yugoslavia.' As Phillips has noted (1998), in the struggles for control of the prescribed content of the National Curriculum for history in all its versions (DES 1991, Dfe 1995, Dfee/QCA 1999), to call for the inclusion of a whole raft of voices and viewpoints in historical narratives of the nation is to court controversy.

If black identities in the United Kingdom, as well as others, are being continually reforged in such ideological cauldrons, how does this impact on a child in a Key Stage 3 (11-14) history classroom. How do children from ethnic minority backgrounds and even more, those with more complex patterns of ancestry see themselves? How do they relate to a history curriculum that in its prescribed content preserves much of a conservative, 'our island story', framework of the past? Is it possible to reconcile the apparently irreconcilable? Is there a way through?

The new government emphasis on Citizenship gives a potentially valuable opportunity to find a structure for teaching about aspects of identity. The concept of multiple identity - that is, simultaneously belonging to a number of different communities at once - can be a way of formalising the reality that many children and adults live with from day to day.

We may identify ourselves through our family upbringing in particular local communities which may possess religious, ethnic or class differences to that of the locality in which they are set. A Muslim girl from an Asian background in Bradford, 
might assert her religious identity at school by contrast with her many white classmates while stressing her Britishness at home, as a form of adolescent independence in a traditional Asian family. Living in Scotland, a child might choose to call themselves Scottish before being called British. They might prefer to be called European instead of British. An Ulster Protestant might claim to be simultaneously British and Irish but never English. The concept of identity is wrapped up with notions of citizenship. Heater's (1998) model of multiple or layered citizenship used as a pedagogical model would allow any number of varied combinations of identity to be found among the school population of the United Kingdom to be accepted.

With regard to the history curriculum, such a degree of pluralism has already been incorporated into the National Curriculum of history. One of the required key elements for Key Stage 3 History states that pupils should be taught:

a) to describe and analyse the relationships between the characteristic features of the periods and societies studied including the experiences and range of ideas, beliefs and attitudes of men, women and children in the past.

b) about the social cultural, religious and ethnic diversity of the societies studied, both in Britain and the wider world.

So the complexities of layered citizenship in the present should already be bolstered by the expectations of the way history is taught in class. Although at first sight the areas of study for the National Curriculum for England at Key Stage 3 outline a traditional framework of British history from 1066 onwards, there is a requirement to incorporate potentially diverse narratives within and across the various periods. This allows teachers to make selections of content from the breadth of study that can readily reflect black history and other narratives reflecting varying emphasis.

It is quite common to find secondary history departments teaching the black peoples of the Americas - a Key Stage 3 area of study that embraces the Atlantic slave trade and its abolition. Yet the resources departments use for teaching this topic (by which I mean textbooks, worksheets and the like) sometimes tend to portray blacks either as helpless victims or in a heroic mode. The resources themselves have emerged out of an old discourse within the historiography of the slave trade and its abolition. This discourse polarises between two extremes. One is a traditionally Euro-centric tribute to white abolitionists, where blacks appear mostly as passive victims and recipients of freedom. Much contemporary documentary material supports this view as it was produced by white abolitionists themselves. Alternatively a more radical, Afro-centric view, stresses the heroism of blacks and the role they played in their own liberation. A recent film from Stephen Spielburg called 'Amistad' dramatises this kind of interpretation as did the 1970's television series 'Roots'. This series in itself reflects the change of black American identification from 'coloured' to 'AfroAmerican', 'the term adopted since the 1960's by black consciousness movements of all kinds, highlights the tremendous preoccupation with historical roots' (Samuel, 1994).

Bernie Grant would probably have supported an Afro-centric interpretation of the slave trade and its abolition. He might even have dubbed the traditional Euro-centric view as 'racist', with some justification. A post-modern view of history would readily allow any such competing narrative, claiming to overturn a traditional 'white' one (such a view might have the additional virtue of deriving from an oppressed minority itself). 
So how can secondary history departments teach this period in some kind of coherent way? In my own view, to accept the ultimate conclusion of postmodernism that 'all interpretations are equally valid' would be disastrous. At the heart of the National Curriculum for history the current strand of skills, knowledge and understanding 'Historical Interpretations' has been evolving in history teaching for over ten years. Macaleavy (1998) defined an interpretation as any 'conscious reflection on the past', made up of a mixture of 'fact and fiction, imagination and point of view.... dependent for its historical worth on, among other things, purpose and intended audience.' This implies that any interpretation of the past, from whatever viewpoint can be rigorously tested for its historical validity to the same standard. Yet this same rigour of analysis is sometimes not applied to minority narratives for fear of causing offence. As Downes (1993) claimed: 'the politics of identity.... rests on a disturbing epistemological ground. Only those who share the group's identity and have lived its experiences can know what it means to be black, a woman.... in an America constructed as white, Anglo-Saxon and Protestant.' This kind of reasoning can be used to attack an opposing view of history when supported by an historian who does not come from that particular group.

As Evans (1997) points out, if the study of history is driven by primarily political or moral aims 'the scholarship suffers'. 'Facts are mined to prove a case, evidence is twisted to suit a political purpose, inconvenient documents are ignored, sources deliberately misconstrued or misinterpreted.' It is right and proper that black history, long neglected and ignored, should be an object of study in schools history. Grant's identification of British blacks with the Irish, Scots and Welsh can be defended as an historical interpretation but it can also be challenged. For just as there is no single 'white history', there are also diverse black histories. To be 'black and British' for a teenager from an ethnic minority background, may well be important to reinforcing that child's identity in the present. But if Britishness itself ultimately disappears and with it, Grant's particular view of the past, where does that leave the teenager as an adult? Probably confused. How much better to teach about the past, but also equip children with the cultural awareness to deconstruct any interpretation for themselves. Within the scope of school history teaching, there is every reason to present varying historical interpretations, not as though they were equally valid but as subject to the same analytical framework as rival historical points of view. Hennessy et al commented in 1991: 'History is a contested subject...I have a daughter who teaches in a big comprehensive in North London....lots of Irish children, lots of AfroCaribbean children, and lots of children from the sub-continent. And it is contested, and it is discussed and so it should be.' As Evans says 'black history deserves to be treated with scholarly rigour and care as much as white history does.' Children in history lessons deserve no less.

\section{References}

Colley, L. (1994) Britons. Forging the Nation 1707-1837 Yale U.P.

Crick, B. (1998) Education for Citizenship and the Teaching of Democracy in School: Final Report of the Advisory Group on Citizenship London, QCA. Davies, N. (2000) The Isles: A History Macmillan.

DES (1991) The National Curriculum for History London, HMSO.

DfE (1995) History in the National Curriculum London London, HMSO.

DfEE/QCA (1999) History The National Curriculum for England London, HMSO.

Downes, L.L. (1993) 'Identity Politics meets the Post modern subject' Comparative Studies in Society and History (35) p. 416.

Evans, R. (1997) In Defence of History London, Granta Books.

Grosvenor, I. (1999) "History for the Nation': Multiculturalism and the Teaching of History' in eds. J. Arthur and R. Phillips, History Teaching_London,_RoutledgeFalmer. 
Heater, D. (1998) The Elements of Citizenship London, The Citizenship Foundation. Hennessy et al. (1991) The History of nations Chicago, PUSH (People United to Save Humanity) Newsletter.

Kerridge, R. (1998) The Story of Black History Brinkworth, Claridge Press.

Lang, S, (1999) 'Democracy is not boring' Teaching History (96).

Lipstadt, D.E. (1993) Denying the Holocaust. The Growing Assault on Truth and

Memory The Vidal Sassoon International Centre for the Study of anti-Semitism, The University of Jerusalem.

Lowenthal, D. (1997) The Heritage Crusade and the Spoils of History London, Viking. Macaleavy, T. (1998) Address to the Historical Association Education Conference.

McKiernan, D. (1993) 'History in a National Curriculum: Imagining the Nation at the End of the $20^{\text {th }}$ Century' Journal of Curriculum Studies Vol. 25.

National Curriculum Council (1993) Teaching History at Key Stage 3, NCC.

Paxman, J. (1998) The English: A Portrait of a People London, Michael Joseph.

Phillips, R. (1998) History Teaching, Nationhood and the State: A Study of

Educational Politics London, Cassell.

Rothenberg, P. (1992) Race, Class and Gender in the United States: An Integrated

Study (Ed...), $2^{\text {nd }}$ Edition New York, St.Martin's Press.

Samuel, R. (1994) Theatres of Memory London,Verso.

Tebbit. N. (1997) The Guardian, 9 October

White, H. (1978) Tropics of Discourse: Essays in Cultural Criticism Baltimore, Johns Hopkins University Press.

Wrenn, A. (1998) 'Build it in, don't bolt it on, history's opportunity to support critical citizenship' Teaching History (96).

Zinn. H. (1994) 'Why students should study history' in Bigelow, B., Chistenson, L., Karp, S., Miner, B., and Peterson, B. (Eds.) Rethinking Our Classrooms: Teaching for Equity and Justice Milwaukee WI, Rethinking schools Ltd. www.rethinkingschools.org 